\title{
The expression of the primigenic dominance in the flowering and fruit set of selected apple cultivars on different growth inducing rootstocks
}

\author{
Racskó, J. ${ }^{1}$, Szabó, Z. ${ }^{1}$, Apáti, F. ${ }^{2}$ \& Nyéki, J. ${ }^{1}$ \\ ${ }^{I}$ Institute for Research and Development, University of Debrecen, 4032 Debrecen, 138 Böszörményi, Hungary, \\ Email: racsko@agr.unideb.hu \\ ${ }^{2}$ Department o farm Business Mangement, Faculty of Agricultural Economics and Rural Development, \\ University of Debrecen, 4032 Debrecen, 138 Böszörményi, Hungary,Email: fapati@agr.unideb.hu
}

Summary: Authors investigated the expression of the primigenic dominance in the flowering and fruit from open and self pollination of four apple cultivars ('Gala Royal', 'Golden Smoothee', Pink Lady' and 'Vista Bella') during two consecutive years in Western Hungary on three different growth inducing rootstocks (M. 9, MM. 106 and seedling). There were not significant differences in the effect of the rootstocks on the flowering order in a flower cluster. Significant difference in the fruit set in open pollination was found among individual flowers in a cluster, mostly between the king bloom and the second flower. The rate of the fruit set from self-pollination was very low without any significant difference among individual flowers in the cluster.

Key words: apple, primigenic dominance, flowering, king bloom, fruit set

\section{Introduction}

\section{Competition between the vegetative and generative organs}

The relation between growth of shoots and fruit set is continuously changing during the growing season (Soltész, 2002). As generally recognised, the young fruit primordia still contain green chloroplasts and photosynthesise actively and contribute to their own provision (Szalai, 2003). Later, they loose that ability, and the function of source and of sink is assigned to different organs already (Atkinson et al., 2001). The products of photosynthesis from the leaves are transported by the phloem to the young fruits. If the source and consequently the transport are restricted (e.g. when the leaves of the short shoots were discarded), the fruits will drop. On the contrary, Atkinson et al. (2001) reported instead of fruit drop a reduction of the fruit size. The low relation of leaf area per number of fruits caused fruit drop at the twoweek interval of approaching harvest time only.

The number of fruits maintained on the tree depends on the sum of organic nutrients furnished by the leaves nearby, whereas the rest is doomed to be dropped. The photosynthetic apparatus of the tree is charged by both, the growing fruits as well as the growing shoots (Szalai, 2003). According to Petrov (1973), in peach, the fruit charge depends not so much from the volume of the fruits but rather from the number of fruits. The development of the endocarp of the stone is highly influenced by the competition of the vegetative organs of the tree (Timon, 1992). Brunner (1982 cit. Soltész, 2002), on the other hand, refers to the balance expressed by the ratio of leaves and fruits. At the time of the shed of petals, in apple 1-4 leaves are needed by one fruit set, around the June drop 10-15 leaves and at the end of fruit development 40 leaves provide the fruits. Relatively, higher leaf area is necessary for fruits set more than one per inflorescence and fruit drop did not occur (e.g. in 'Paulared', 'Summerred', 'Golden Delicious', 'Fuji', 'Fiesta') (Soltész, 1997).

The weak development of the leaf area around bloom (i.e. a low leaf/flower ratio) reduces the chances of fruit set and induces fruit drop. At 5-7 weeks after petals shed, the vigorous shoot growth (at warm weather) favours fruit drop. Later, on the other hand, slow growth of shoots may accentuate June drop by the insufficiency of leaf area. Apple varieties known to be weak in fruit set ('Cox's Orange Pippin', 'Starking' etc.) are afflicted by fruit drop caused by vigorous shoot growth even at a relatively low charge of fruits set. The inhibiting effect of the shoots is always influenced by their provision of nutrients on the tree or locally on the branch. Therefore, fruit drop may differ between trees of the same vigour of shoot growth. Fruit drop may vary within the same tree according to the position of different branches (Soltész, 2002).

A clear correlation is evident in apple between the shoot growth and the tendency to fruit drop. Trees of strong shoot growth used to drop more fruit the weak growing trees, 
which may keep often supernumerary fruit primordia (mummies) on the fruiting structures. Poma \& Treccani (1982 cit. Soltész, 2002) proved the role of vigorous (water) shoots in fruit drop. Vigorous shoot growth is responsible also for fruit drop, in blueberry, significantly. Fruit drop in pecan, shoot growth and fruit drop is also related with each other.

It is also an interesting observation that leaves may stimulate fruit abscission (Dávid, 1980). It is attributed to the translocation of ABA from the leaves to the fruits. Goren \& Goldschmidt (1970) indicated that mature leaves of Cytrus contain much $\mathrm{ABA}$. The same was found in apple leaves by Pieniazek \& Rudnicki (1967), in Acer (maple) and Betula (birch) by Eagles \& Wareing (1964) and in Coleus by Chang (1971). Mature leaves are able to suppress the growth of apical buds even against the influence of $\mathrm{GS}_{3}$ spray (Cooper et al., 1969). At the same time, young leaves may delay the abscission of ripe fruits, whereas mature leaves promote the abscission of fruits by stimulating the transport of $\mathrm{ABA}$ (Dávid, 1980).

\section{Competition between the generative organs}

It is commonly accepted that in a large mass of flowers or fruit primordia, the accumulation of organic matter is not optimal causing a vigorous drop of fruit (Racskó, 2005). As a rule, a supernumerary bloom resulted in a low rate of fruit set (Pethô, 1993). The physiological explanation is forwarded that the flower or fruit set, which started growing earlier, becomes dominant in relation to other flower or fruits lagging relatively behind (Bubán, 2003). This type of dominance is called primogenous (Bangerth, 1990).

In the flower buds of the apple, the flower of apical position is always dominant and starts growing first (Bubán \& Faust, 1982). In this case, the dominance is due to its earliness rather than to its position. Most pear varieties, as well as gooseberry (Bubán, 1996) develop the first flower in basal position within the inflorescence and are corresponding to the apical flower of apple. Those flowers are the most developed, have the best chance to grow fruit, and are less exposed to be dropped. However, the excision of this first flower passes the same chances to the following flowers of the inflorescence (Ferree \& Warrington, 2003).

The correlative signal of dominance induces the process of abscission by $\mathrm{ABA}$ and ethylene, as the latter is produced in senescent cells positioned distally to the respective abscission layer. As auxin (IAA) is acting against the effect of ethylene, the latter appears first at the basis of fruit stem as a factor preventing auxin to inhibit abscission in the AZ. Its further effects are: i.) inhibition of the synthesis and translocation of IAA, and ii.) stimulation of decomposition, binding and formation of conjugates with IAA.

All of those processes, except the binding of IAA are manifestly documented of being subject to the influence of ethylene by the fact that fruits treated with ethylene lost their IAA content significantly. The supposed mechanism, however, could not be explored under in vivo conditions yet.
In the processes the role of gibberellins is also involved because the diffusion of them from the growing tips and growing fruits is supposed to stimulate the movement of auxin (Bangerth, 1993). The examination of the phenomenon of correlative dominance a significant role is assigned to the cytokinins too (Greene, 1989; Neri et al., 1992; Costa et al., 1995; Costa et al., 2001). Cytokinins applied to dominated fruits seem to be antagonists of IAA (Bangerth, 1993). Occasionally sprayed on apple, the number of fruits diminished (fruit drop increased), therefore, it may use for fruit thinning. The latter effect is supposed to stem from the stimulation of lateral branching (Greene, 1989) or reduces the IAA export especially the dominated fruits, and as a result, fruit drop is induced.

\section{Materials and methods}

\section{Experimental site and plant material}

This study was conducted for 2 consecutive years (2006 and 2007) at Nagykutas, Western Hungary on apple cultivars 'Gala Royal', Golden Smoothee', 'Pink Lady' and 'Vista Bella'. Trees were planted in 1999 at a spacing of $3.5 \times 0.54$ $\mathrm{m}$. Each cultivar was grafted onto three different growth inducing rootstocks: M.9 (weak), MM.106 (moderate) and seedling (with strong vegetative vigour). Site and soil preparation, fertilization and pest control were according to local recommendations and needs. Tree training was done according to commercial practices, with the general goal of a spindle-shaped canopy. Irrigation and fruit thinning was not used. Assessments were made on 20 trees per each rootstock scion combination. Means of the data are included in the tables and on the figures. Assessed trees were selected before flowering in four blocks per combinations with five trees in each block.

\section{Measured and calculated parameters}

Flowering time: the beginning of bloom was counted from the opening of the first flower in a flower cluster. The observations were made at 2 p.m. everyday during the whole flowering period.

Fruit set: The rate of the fruit set from open and selfpollination was expressed as a percentage of the designed flowers examined. Each flower in the cluster was separated and the ratio of fruit set was expressed as a fruit set of each individual flowers.

\section{Results and discussion}

\section{Flowering time}

The expression of the primigenic dominance in the flowering time can be seen in the Tables $1-3$ and on the Figures 1-2. In the table 1, the time differences are shown in 
1. April 19, 2006

3. April 22, 2006

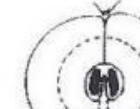
(1)
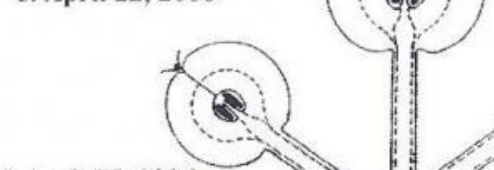

5. April 27, 2006

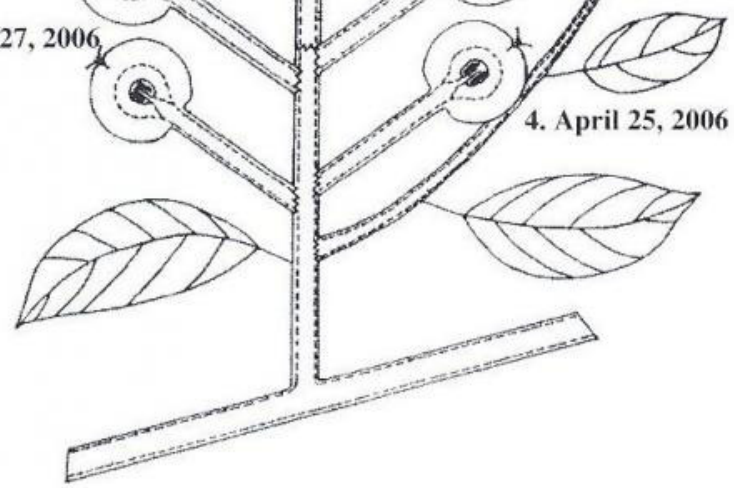

Figure 1 The expression of the primigenic dominance in the flowering time of 'Pink Lady' on M.9 rootstock (Nagykutas, 2006)

the years 2006 and 2007 for 4 selecred apple cultivars grafted onto M.9 rootstock. In 2006, the secondly developed flowers opened 1.3 days later in average than the king bloom. The flowering times of the third, fourth and fifth flowers were observed $2.15,2.7$ and 3.15 days later, respectively, than the first one. For 'Gala Royal' sixth flower was also registered which opened 3.4 days later than the king bloom. Significant differences from the average can be found in the Table 1 . The smallest difference was observed for 'Golden Smoothee' and the biggest for 'Vista Bella'.

In 2007, similar tendency was observed to 2006, the individual and average values are, however, lower in 2007. It was partly caused by the strongly increased spring temperature before flowering, i.e. the speed of the flowering
Table 1 The expression of the primigenic dominance int he flowering times of the individual flowers in a cluster for four selected apple cultivars in 2006 and 2007 on M.9 rootstock. The values represent the time difference between the opening of the king bloom and the other individual flowers in a cluster

\begin{tabular}{|l|l|c|c|c|c|c|c|}
\hline \multicolumn{2}{c}{} & \multicolumn{1}{c|}{ Flowers in the order of the blooming } \\
\hline Year & \multicolumn{1}{|c|}{ Cultivar } & $\mathbf{1}^{\text {st }}$ & $\mathbf{2}^{\text {nd }}$ & $\mathbf{3}^{\text {rd }}$ & $\mathbf{4}^{\text {th }}$ & $\mathbf{5}^{\text {th }}$ & $\mathbf{6}^{\text {th }}$ \\
\hline \multirow{2}{*}{2006} & Gala Royal & 0 & 1.3 & 2.2 & 2.8 & 3.3 & 3.4 \\
& Golden Smoothee & 0 & 0.7 & 1.7 & 2.2 & 2.7 & - \\
& Pink Lady & 0 & 1.1 & 1.9 & 2.7 & 2.7 & - \\
& Vista Bella & 0 & 2.1 & 2.8 & 3.1 & 3.9 & - \\
\hline Average & 0 & 1.3 & 2.15 & 2.7 & 3.15 & 3.4 \\
\hline \multirow{2}{*}{2007} & Gala Royal & 0 & 1.2 & 2.3 & 2.6 & 2.9 & - \\
& Golden Smoothee & 0 & 1.1 & 1.6 & 1.7 & 1.9 & - \\
& Pink Lady & 0 & 0.9 & 1.5 & 2.2 & 2.7 & 2.9 \\
& Vista Bella & 0 & 1.5 & 2.2 & 3.2 & 3.5 & - \\
\hline Average & 0 & 1.18 & 1.9 & 2.43 & 2.75 & 2.9 \\
\hline
\end{tabular}

process was increased and the time difference in the flowering among the individual flowers was decreased. The primigenic dominance was still remained, its effect was, however, not really expressed as in 206 . The smallest difference ( 0.9 day) between the first two flowers in the cluster was observed for 'Pink Lady' in this year. The biggest difference can be seen for 'Vista Bella' as in 2006.

In the Table 2, the data of the above mentioned four cultivars and two years can be found on MM.106 rootstock. In 2006, for 'Gala Royal' and in 2007, for 'Gala Royal', 'Pink Lady' and 'Vista Bella' at least five flowers were found in a flower cluster. In the other cases, six flowered cultivars were also observed. In 2006, the smallest differences in the flowering times of the king bloom and the second flower were shown by 'Vista Bella', the biggest differences by 'Gala Royal'. The biggest difference between the firstly and lastly opened flowers was observed for 'Golden Smoothee' (3.3 days) and 'Pink Lady' (3.4 days).
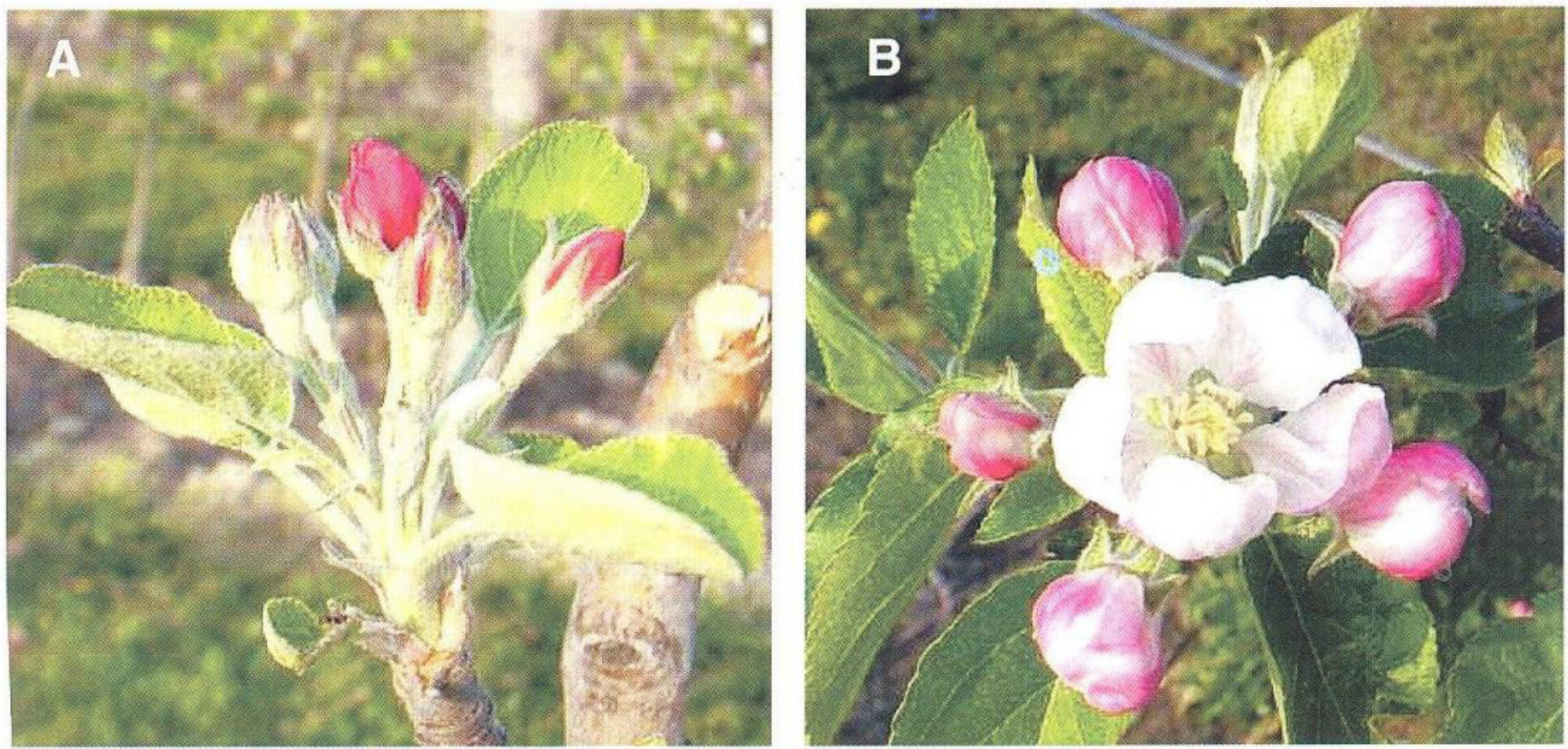

Figure 2 The expression of the primigenic dominance in the flowering of the flowers in a cluster of 'Pink Lady' (A) and 'Golden Smoothee' (B) 
Table 2 The expression of the primigenic dominance int he flowering times of the individual flowers in a cluster for four selected apple cultivars in 2006 and 2007 on MM. 106 rootstock. The values represent the time difference between the opening of the king bloom and the other individual flowers in a cluster

\begin{tabular}{|c|c|c|c|c|c|c|c|}
\hline & & Flo & $\sin t$ & e ord & of th & bloor & ing \\
\hline Year & (4) Cultivar & $1^{\text {st }}$ & $2^{\text {nd }}$ & $3^{\text {rd }}$ & $4^{\text {th }}$ & $5^{\text {th }}$ & $6^{\text {th }}$ \\
\hline 2006 & Gala Royal & 0 & 1.5 & 2.1 & 2.5 & 2.8 & - \\
\hline & Golden Smoothee & 0 & 1.0 & 1.8 & 2.4 & 2.9 & 3.3 \\
\hline & Pink Lady & 0 & 1.1 & 2.1 & 2.7 & 3.2 & 3.4 \\
\hline & Vista Bella & 0 & 0.9 & 1.9 & 2.3 & 2.4 & 2.4 \\
\hline Avera & & 0 & 1.13 & 1.98 & 2.48 & 2.83 & 3.03 \\
\hline 2007 & Gala Royal & 0 & 1.4 & 1.9 & 1.9 & 2.3 & - \\
\hline & Golden Smoothee & 0 & 1.2 & 1.8 & 1.8 & 2.2 & 2.6 \\
\hline & Pink Lady & 0 & 1.7 & 3.2 & 3.2 & 3.7 & - \\
\hline & Vista Bella & 0 & 1.7 & 2.9 & 2.9 & 3.1 & - \\
\hline Aver: & & 0 & 1.5 & 2.45 & 2.45 & 2.83 & 2.6 \\
\hline
\end{tabular}

They were the sixth flowers in the cluster. The time differences among flowers was getting shorter from the king bloom on MM.106 rootstock, from the first to the sixth flower, the following average values were calculated: 1.33 days, 0,85 day, 0.5 day, 0.35 day and 0.2 day.

In 2007, the effect of the warm spring temperature was expressed in the flowering time on MM.106 stock, too. It was interesting that the time difference between the first and the second flowers was almost doubled (1.7 days) for "Vista Bella'. The time difference was significant between the first and the last flowers for 'Pink Lady' (3.7 days). The smallest difference was found for 'Gala Royal' (2.3 days).

Table 3 shows the time differences for seedling rootstock. In 2006, the king bloom opened its flower 1.43 days earlier in average than the second one. The third, fourth and fifth flowers bloomed 2.23 days, 2.95 days and 3.13 days later in average, respectively. Flower clusters with six flowers were not found in both years on seedling rootstock. The smallest difference between the first two flowers was observed for 'Golden Smoothee', and the biggest for 'Pink Lady'. The primigenic dominance was also the most expressed between the first two flowers on seedling rootstock.

In 2007, similarly to 2006, all examined cultivars had five flowers int he flowers cluster except 'Vista Bella'. The smallest time difference between the opening of the king bloom and the second flowers was found for 'Golden Smoothee' ( 0.9 day), the biggest difference for 'Vista Bella' (1.3 days). The time difference between the first and last flowers was realatively low (2.63 days in average) partly because of the low number of the individual flowers in a cluster.

The Figure 3. compiled on the data of the Tables $I-3$ shows no significant difference in the opening of the flowers in a cluster among different growth inducing rootstocks. The trends of the functions are quite similar until the fifth flower, then a little more difference can be seen between M.9 and MM.106. To sum it up, the different vigorous rootstocks had the same or similar effect on the expression of the primigenic dominance in the flowering times of the individual flowers in a cluster.
Table 3 The expression of the primigenic dominance int he flowering times of the individual flowers in a cluster for four selected apple cultivars in 2006 and 2007 on seedling rootstock. The values represent the time difference between the opening of the king bloom and the other individual flowers in a cluster

\begin{tabular}{|l|l|c|c|c|c|c|c|}
\hline \multicolumn{9}{|c}{ Flowers in the order of the blooming } \\
\hline Year & \multicolumn{1}{|c|}{ Cultivar } & $\mathbf{1}^{\text {st }}$ & $\mathbf{2}^{\text {nd }}$ & $\mathbf{3}^{\text {rd }}$ & $\mathbf{4}^{\text {th }}$ & $\mathbf{5}^{\text {th }}$ & $\mathbf{6}^{\text {th }}$ \\
\hline 2006 & 0 & 1.3 & 1.9 & 2.4 & 2.6 & - \\
& Gala Royal & 0 & 1.1 & 1.9 & 2.6 & 2.7 & - \\
& Golden Smoothee & 0 & 2.1 & 2.9 & 3.7 & 4.1 & - \\
& Pink Lady & 0 & 1.2 & 2.2 & 3.1 & - & - \\
\hline & Vista Bella & 0 & 1.43 & 2.23 & 2.95 & 3.13 & - \\
\hline Average & 0 & 1.2 & 2.1 & 2.5 & 2.7 & - \\
\hline 2007 & Gala Royal & 0 & 0.9 & 1.6 & 2.2 & 2.6 & - \\
& Golden Smoothee & 0 & 1.2 & 1.9 & 2.4 & 2.6 & - \\
& Pink Lady & 0 & 1.3 & 1.9 & 2.4 & - & - \\
\hline
\end{tabular}

\section{Fruit set}

The expression of the primigenic dominance in fruit set for 'Gala Royal' cultivar can be seen on the Figure 4. Significant difference in the fruit set in open pollination was found among individual flowers in a cluster, mostly between the king bloom and the second flower. The highest rate of fruit set was for the king bloom on M.9, MM106 and seedling stocks, the calculated values are $19.4 \%, 20.4 \%$ and $13.6 \%$, repsectively. So, there was no significant difference among rootstocks.

Figure 5 represents the fruit set of the individual flowers from self-pollination (geitonogamy) for 'Gala Royal'. The rate of the self pollination was very low for this cultivar, the king bloom fertilised in $2.3 \%$ on M.9, $1.8 \%$ on both MM.106 and seedling rootstocks. In the case of the second flower, only $0.5 \%$ was observed on M.9 and $0 \%$ both on MM.106 and seedling. The third flower showed also a low rate of fruit set: $0.3 \%$ on MM.106 and $0 \%$ on M.9 and seedling. The fourth, fith and sixth flowers were not able to be fertilised.

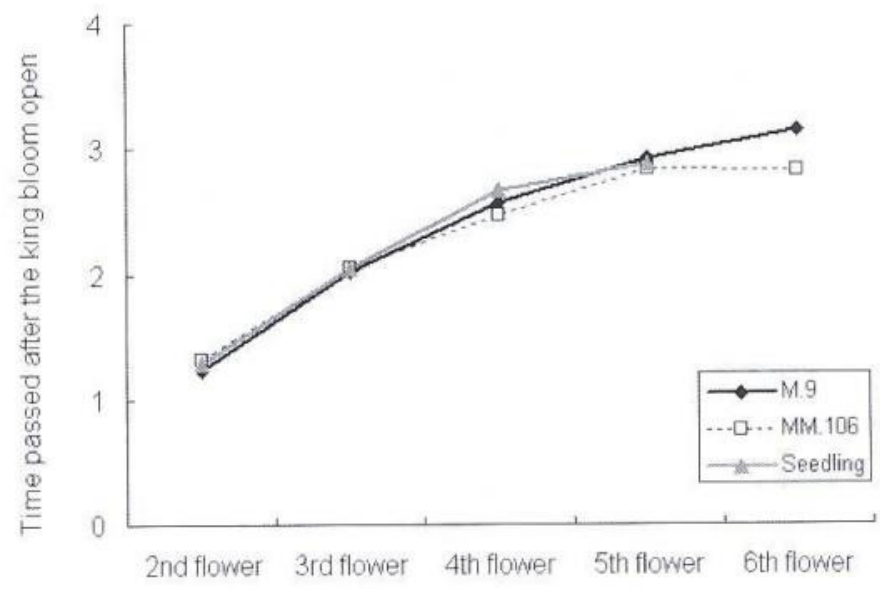

Opening order of the flowers in the cluster

Figure 3 The expression of the primigenic dominance in the flowering times of the individual flowers in a cluster on three different growth inducing rootstocks (the average of the cultivars and years). The values represent the time difference between the opening of the king bloom and the other individual flowers in a cluster 


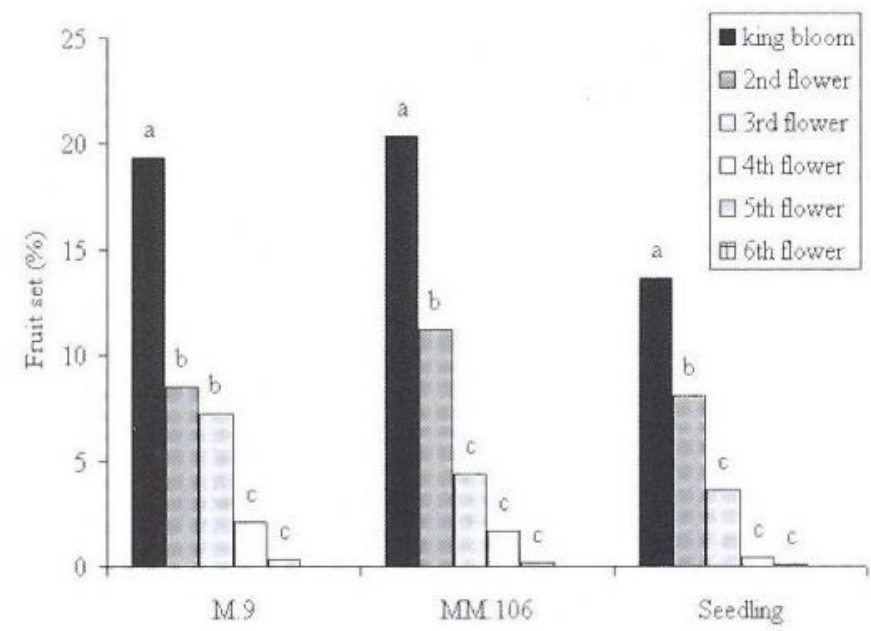

Figure 4 The expression of the primigenic dominance in the fruit set from open pollination for 'Gala Royal' on three different growth inducing rootstocks. The figure represents the average of 2006 and 2007. Significant differences at $\mathrm{P}=5 \%$ are indicated by the different letters above the columns

\section{References}

Atkinson, C.J., Else, M.A., Stankiewicz, A.P. \& Webster, A.D. (2001): Limited availability of photoassimilates: effects ont he abscission of sweet cherries. Acta Hort. 557: 457-463.

Bangerth, F. (1990): Polar auxin transport in fruit trees in relation to fruit drop. Acta Hort. 275: 461-468.

Bangerth, F. (1993): Polar auxin transport as a signal in the regulation of tree and fruit development. Acta Hort. 329: 70-76.

Bubán, T. (1996): Flower development and formation of sexual organs. In: Nyéki, J. - Soltész, M. (szerk.) (1996): Floral biology of temperate zone fruit trees and small fruits. Akadémiai Kiadó, Budapest, 3-54.

Bubán, T. (2003): Hormonal spects of flower formation and fruit set. In: Kozma, P., Nyéki, J., Soltész, M. \& Szabó, Z. (szerk.) (2003): Floral biology, pollination and fertilisation in temperate zone fruit species and grape. Akadémiai Kiadó, Budapest, 3-24.

Bubán, T. \& Faust, M. (1982): Flower bud induction in apple trees: Internal control and differentiation. Hort. Rev. 4: 174-203.

Chang, Y. (1971): The movement of indoleacetic acid in Coleus petioles as affected by abscisic acid. Ph.D. Thesis, Princeton, University.

Cooper, W.C., Young, R. \& Henry, W.H. (1969): Effect of growth regulators on bud growth and dormancy in citrus as influenced by season of year and climate. Proc. Int. Citrus Symp., Ist., $301-314$.

Costa, G., Corelli-Grappadelli, L. \& Bucchi, F. (2001): Studies on apple fruit abscission and growth as affected by cytokinins. Acta Hort. 557: 243-251.

Costa, G., Succi, F., Quadretti, R., Morigi, M. \& Miserocchi, O. (1995): Effect of CPPU and pollination on fruiting performance, fruit quality and storage life of kiwifruit (cv. Hayward). Acta Hort. 444: 459-466.

Dávid, M. (1980): Vegyszeres termésszabályozással a gépi betakarításért. Mezốgazdasági Könyvkiadó, Budapest.

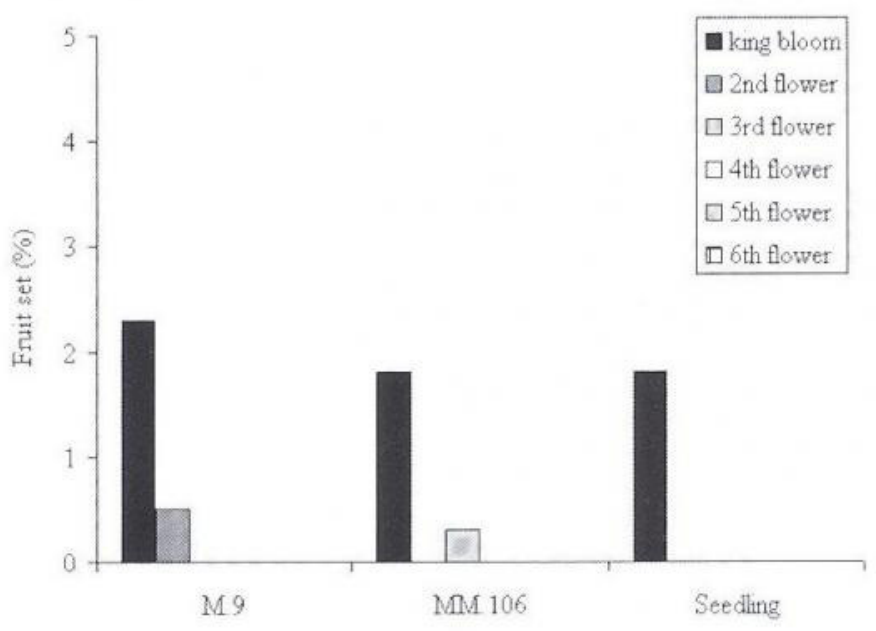

Figure 5 The expression of the primigenic dominance in the fruit set from self-pollination for 'Gala Royal' on three different growth inducing rootstocks. The figure represents the average of 2006 and 2007 . Significant differences among flowers were not found at $\mathrm{P}=5 \%$

Eagles, C.F. \& Wareing, P.F. (1964): The role of growth substances in the regulation dormancy. Physiol. Plant. 17: 697-709.

Ferree, D.C. \& Warrington, I.J. (szerk.) (2003): Apples: Botany, production and uses. CAB International.

Goren, R. \& Goldschmidt, E.E. (1970): Regulative systems in the developing citrus fruit. I. The hormonal balance in orange fruit tissues. Physiol. Plant. 23: 937-947.

Greene, D.W. (1989): CPPU influences McIntosh apple crop load and fruit characteristics. HortScience 24: 94-96.

Neri, D., Biasi, R., Tartarini, S., Sugiyama, N., Giuliani, R., Sansavini, S. \& Costa, G. (1992): Sink strength as related to CPPU mobility and application site in apple and kiwifruit spurs. Acta Hort. 329: 77-80.

Pethố, M. (1993): Mezôgazdasági növények élettana. Akadémiai Kiadó, Budapest.

Petrov, A.A. (1973): The reduction in growth of peach trees brought about by fruiting. Dokl. Szelh. Hoz. A. G. Dimitrova, Szofija. 6. (1): 25-32.

Pieniazek, J. \& Rudnicki, R. (1967): The presence of Abscisin II. in apple leaves and apple fruit juice. Bull. Acad. Pol. Sci., Cl. V. 15: 251-254.

Racskó, J. (2005): Crop load, fruit thinning and their effects on fruit quality of apple (Malus domestica Borkh). J. Agr. Sci. (in press)

Soltész, M. (2002): Alma In: Nyéki, J. - Soltész, M. - Szabó, Z. (ed.) (2002): Fajtatársítás a gyümölcsültetvényekben. Mezôgazda Kiadó, Budapest, 72-150.

Soltész, M. (1997): Terméskötốdés és -ritkítás. In: Soltész, M. (ed.) (1997): Integrált gyümölcstermesztés. Mezógazda Kiadó, Budapest, 309-331.

Szalai, I. (2003): Gyümölcsfejlódés és -érés, In: Papp, J. (ed.) (2003): Gyümölcstermesztési alapismeretek. Mezógazda Kiadó, Budapest, 329-338.

Timon, B. (ed.) (1992): Ôszibarack. Mezốgazda Kiadó, Budapest. 